\title{
Electrochemical Production of Syngas from CO2 Captured in Switchable Polarity Solvents
}

L. A. Diaz, N. Gao, B. Adhikari, T. E. Lister, E. J. Dufek, A. N. Wilson

December 2017

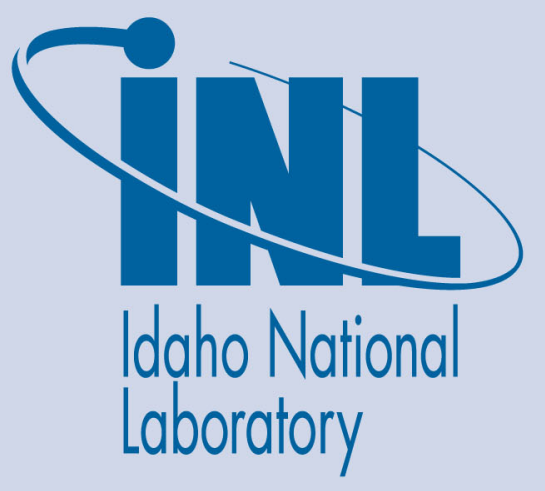

The INL is a U.S. Department of Energy National Laboratory operated by Battelle Energy Alliance 


\title{
Electrochemical Production of Syngas from $\mathrm{CO} 2$ Captured in Switchable Polarity Solvents
}

\author{
L. A. Diaz, N. Gao, B. Adhikari, T. E. Lister, E. J. Dufek, A. N. Wilson
}

December 2017

Idaho National Laboratory Idaho Falls, Idaho 83415

http://www.inl.gov

Prepared for the U.S. Department of Energy Office of Nuclear Energy Under DOE Idaho Operations Office

Contract DE-AC07-05ID14517 


\title{
Electrochemical Production of Syngas from $\mathrm{CO}_{2}$ Captured in Switchable Polarity Solvents
}

Luis A. Diaz ${ }^{\mathrm{a},}{ }^{*}$, Ningshengjie Gao ${ }^{\mathrm{a}}$, Birendra Adhikari ${ }^{\mathrm{a}}$, Tedd E. Lister ${ }^{\mathrm{a}}$, Eric J. Dufek ${ }^{\mathrm{b}}$, and Aaron D. Wilson ${ }^{\mathrm{a}}$

\author{
${ }^{a}$ Biological and Chemical Processing \\ ${ }^{\mathrm{b}}$ Energy Storage and Transportation Systems \\ Idaho National Laboratory \\ P.O. Box 1625 \\ Idaho Falls, ID 83415 \\ * Corresponding author: luis.diazaldana@inl.gov \\ Submission to Green Chemistry
}

\section{GRAPHICAL ABSTRACT}

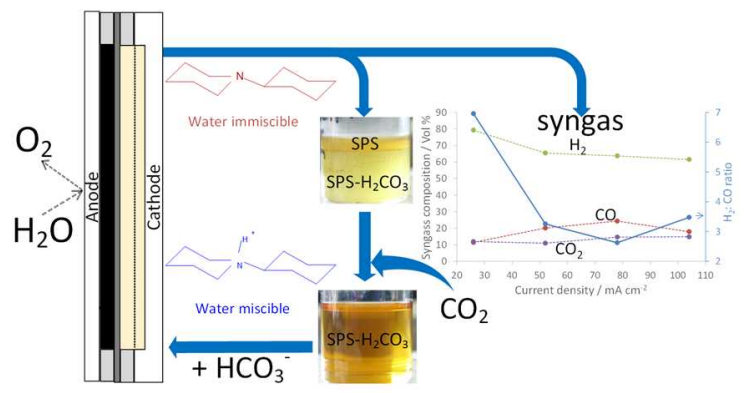

Switchable polarity solvents allowed for the first time the electrochemical reduction of captured $\mathrm{CO}_{2}$ for an efficient production of syngas

\section{ABSTRACT}

An operational advantage that enables the deployment of technologies for the valorization of $\mathrm{CO}_{2} \mathrm{can}$ be achieved through the integration of the capture and conversion technologies. In that perspective, switchable polarity solvents (SPS) were assessed as re-usable capture-electrolyte media for the electrochemical production of syngas at low temperatures and pressures. A polymer electrolyte membrane cell was used to liberate captured $\mathrm{CO}_{2}$ gas in proximity to the cathode without the addition of $\mathrm{CO}_{2}$ gas. Due to the proximate location of release, the produced syngas had minimal $\mathrm{CO}_{2}$ dilution with 
$\mathrm{H}_{2}: \mathrm{CO}$ ratios between 2 to 4 . For the first time captured $\mathrm{CO}_{2}$ has been reduced to $\mathrm{CO}$ with conversions and yields over $70 \%$ and at current densities over $100 \mathrm{~mA} \mathrm{~cm}^{-2}$.

\section{Introduction}

Exploitation of $\mathrm{CO}_{2}$ as a feedstock is of growing research interest that goes beyond the environmental target associated with the abatement of greenhouse gas (GHG) emissions. Technology development is moving toward the generation of value from already available low-cost $\mathrm{CO}_{2}$, which can be used as primary feedstock for the future generation of non-fossil fuels and chemicals. ${ }^{1}$ Parallel efforts are currently underway in the development of supplementary technologies that can be classified as $\mathrm{CO}_{2}$ capture and storage storage (CCS), and $\mathrm{CO}_{2}$ utilization. ${ }^{2,3}$

Post combustion capture of $\mathrm{CO}_{2}$ with primary and secondary alkanolamines to trap the $\mathrm{CO}_{2}$ as carbamates [RNHCOO$]$ is one of the better developed CCS lines of research. ${ }^{4}$ Over 70 years of work have gone into developing amine based CCS in hopes of it becoming industrially relevant technology. ${ }^{3,5}$ However, high energy consumption for the amine regeneration via carbamate decomposition to release $\mathrm{CO}_{2}$ (the inverse of the $\mathrm{CO}_{2}$ absorption enthalpy) is a major draw back and threatened the economic feasibility of the alkanolamine CCS process. ${ }^{6}$ An alternative to alkanolamines are tertiary amines that can capture $\mathrm{CO}_{2}$ as bicarbonate $\left[\mathrm{HCO}_{3}^{-}\right]$and may reduce the energy demands of CCS. ${ }^{6}$ Even still cost efficient CCS does not seem to be feasible, in the long term, without additional generation of value through the utilization of the captured $\mathrm{CO}_{2}$ as feedstock for the production of fuels and chemicals. ${ }^{2,3}$ Combination of capture and utilization (CCU) thus appears to be a superior alternative to the high energy requirements of CCS. ${ }^{7,8}$

Electrochemical reduction of $\mathrm{CO}_{2}$ is one of the technologies that can be coupled with CCS to generate a diversity of value added products, which include but are not limited to alcohols, hydrocarbons, and syngas. ${ }^{9,10}$ However, a previous analysis of the $\mathrm{CO}_{2}$ reduction process feasibility concluded that the two electron product, $\mathrm{CO}$ (or syngas) and formate, are the only products that could conceivably compete with conventional chemical production processes. Any product, requiring more than two electrode transferred per mole of $\mathrm{CO}_{2}$, will cost more to be produced than the current market value. ${ }^{11}$

As a valuable product, syngas is a mixture of $\mathrm{H}_{2}$ and $\mathrm{CO}$, whose composition can be tuned for the synthesis of a variation of fuels and commodity synthetic chemicals, which can substitute fossil derived fuels without changes in the current chemical generation, transportation, and distribution infrastructure. ${ }^{12}$ In aqueous media, and/or in the presence of water, syngas is the most favorable product from the electrochemical reduction of $\mathrm{CO}_{2}$ to $\mathrm{CO}$ since the hydrogen evolution reaction (HER) cannot be completely avoided and unlike formate (the other 2e-product), separates from solution as a gas. Hence, a sustainable green chemical production could be achieved via syngas production from captured $\mathrm{CO}_{2}$ if renewable energy sources are used to power the electrochemical reduction of $\mathrm{CO}_{2} .{ }^{12-15}$

To date, the main technical problems identified as challenges in to scale-up the electrochemical reduction of $\mathrm{CO}_{2}$ are: ${ }^{11} 1$ ) the low solubility of $\mathrm{CO}_{2}$ in aqueous media and 2) mass transfer and kinetic limitations. These problems, combined, result in systems that operate at low current density ca. $20 \mathrm{~mA}$ $\mathrm{cm}^{-2}$ or less, commonly reported in the literature, and require high amounts of $\mathrm{CO}_{2}$ gas to be continuously fed to the electrochemical reactors. ${ }^{11,16,17}$ As a result, slow production rates, low conversion and additional downstream feedstock and products separation are featured. An electrochemical process' current density separates industrial feasible processes from academic curiosities as a systems capital cost and various operational costs are inversely related to the systems operational current density.

Catalyst development, electrolyzer architectures, and electrolyte formulations, have been proposed as alternatives to address the previously mentioned challenges with focus in high current efficiencies for 
CO at meaningful current densities. ${ }^{12,18,19}$ The work of Verma et al. ${ }^{20}$ reported high current densities > $400 \mathrm{~mA} \mathrm{~cm}^{-2}$ and CO Faradaic efficiencies (FE) over $90 \%$ when $3 \mathrm{M} \mathrm{KOH}$ was used as electrolyte in a microfluidic reactor that uses Ag gas diffusion electrodes (GDE). In another work from Dufek et al. ${ }^{17}$ a pressurized system that operates over 15 atm showed the production of syngas at current densities far in excess of $350 \mathrm{~mA} \mathrm{~cm}^{-2}$ with CO FE ca $90 \%$. While these works were able to overcome one of the most significant technology challenges for technology commercialization, both processes required continous addition of stochiometric excess of $\mathrm{CO}_{2}$, which ended in diluted product streams.

One of the main advantages that combining carbon capture process with the electrochemical reduction of $\mathrm{CO}_{2}$ has over standalone $\mathrm{CO}_{2}$ reduction prcesses is that the $\mathrm{CO}_{2}$ feed can be fed to the electrochemical reactor in an aqueous soluition in an already concentrated form. A recent work by Zhang et al. ${ }^{21}$ reported the first attempt to electrochemically reduce $\mathrm{CO}_{2}$ captured in a monoethanolamine medium. However, no electrochemical reduction of captured $\mathrm{CO}_{2}$ was achieved as the system requires the continuous addition of gaseous $\mathrm{CO}_{2}$ as source of free $\mathrm{CO}_{2}$. It has been well established that $\mathrm{CO}_{2}$ and no other associated form is the reducible species. ${ }^{21-23}$ Ionic liquids, which poses other benefits toward the suppression of the $\mathrm{HER}$, have also being tested as capture-electrolyte media for $\mathrm{CO}_{2}$ reduction, ${ }^{20}$ but the need for $\mathrm{CO}_{2}$ gas feed remains.

\section{Technical approach}

As a technological alternative for the reduction of captured $\mathrm{CO}_{2}$, this work proposes use of switchable polarity solvents (SPS) as a CCU technology. SPS (also reported as switchable hydrophilicity solvents $\mathrm{SHS})^{24,25}$ are emerging as an extremely versatile class of materials that can shift polarity upon being exposed to a chemical agent, namely $\mathrm{CO}_{2} \cdot{ }^{24}$ The use of SPS can be extended to many applications as solvent for chemical synthesis, floculation, water treatment and water desalination. ${ }^{7,26-28}$ Insoluble tertiary amines react with $\mathrm{CO}_{2}$ to form soluble ions $\left[\mathrm{HNR}_{3}{ }^{+}\right]$and $\left[\mathrm{HCO}_{3}{ }^{-}\right]$(Sheme 1). ${ }^{4}$ Hence, a novel use is proposed for SPS as capture-electrolyte media for the for the electrochemical production of syngas from $\mathrm{CO}_{2}$.

$$
\begin{aligned}
& \mathrm{SPS}_{\text {(org) }}+\mathrm{CO}_{2 \text { (gas) }}+\mathrm{H}_{2} \mathrm{O} \rightarrow \mathrm{SPSH}^{+}{ }_{(\text {aq) }}+\mathrm{HCO}_{3}^{-} \quad \text { Capture } \\
& \begin{cases}\mathrm{HCO}_{3}^{-}+\mathrm{H}^{+} \rightarrow \mathrm{CO}_{2}+\mathrm{H}_{2} \mathrm{O} & \text { Release } \\
\mathrm{CO}_{2 \text { (gas) }}+\mathrm{H}_{2} \mathrm{O}+2 \mathrm{e}^{-} \rightarrow \mathrm{CO}_{\text {(gas) }}+2 \mathrm{OH}^{-} & \text {Reduction } \\
\mathrm{SPSH}^{+}{ }_{\text {(aq) }}+\mathrm{OH}^{-} \rightarrow \mathrm{SPS}_{\text {(org) }}+\mathrm{H}_{2} \mathrm{O} & \text { Recovery }\end{cases}
\end{aligned}
$$

Scheme 1. $\mathrm{CO}_{2}$ capture and utilization cycle

1-Cyclohexylpiperidine (CHP) was tested as SPS for the capture and electrochemical reduction of $\mathrm{CO}_{2}$ based on high $\mathrm{CO}_{2}$ absorption capacities, up to $189.63 \mathrm{~g} / \mathrm{L}$, compatibility with polymeric systems, and expected low production cost. ${ }^{29-31}$ As capture-electrolyte media for the utilization of $\mathrm{CO}_{2}$, $\mathrm{CHP}$ presents additional ideal characteristics, such as low volatility, effective polar-to-nonolar phase transition, low membrane permeability, and compatibility with a wide range of materials. ${ }^{27}$

A buffer-layer-type cell with a cation exchange (CEM), inspired in the work of Delacourt et al., ${ }^{23}$ was used to perform the electrochemical release and reduction of captured $\mathrm{CO}_{2}$. A scheme of the electrolysis system and a description of the membrane electrode assembly MEA are shown in Figure 1.Water oxidation occurs in the anode side of the electrochemical cell releasing $\mathrm{O}_{2}$ gas and generating $\mathrm{H}^{+}$ions 
that are transferred through the CEM. On the cathode side $\mathrm{H}^{+}$ions create a localized acidic environment that in contact with the $\left[\mathrm{HCO}_{3}{ }^{-}\right]$releasing $\mathrm{CO}_{2}$ for reduction, in-situ, and near the electro-catalyst surface. As a simple acid-base reaction $\mathrm{CO}_{2}$ release should not limit the cathodic process maintaining an adequate $\mathrm{CO}_{2}$ concentration on the surface of the cathode. Upon the release of $\mathrm{CO}_{2}$ the CHP switches polarity back to water insoluble, allowing the recovery and re-utilization of the capture media. Bulk reduction experiments were performed at significant current densities $>25 \mathrm{~mA} \mathrm{~cm}^{-2}$, and for the first time it was demonstrated the reduction of captured $\mathrm{CO}_{2}$, without addition of a stoichiometric excess of $\mathrm{CO}_{2}$ gas, for the production of syngas. As a main result non-diluted syngas can be obtained as product at low temperature and pressures.

\section{Results and discussion}

$\mathrm{GC}$ analysis of the prepared $\mathrm{CHP}-\mathrm{H}_{2} \mathrm{CO}_{3}$ stock solution established that the CHP concentration in the aqueous stock solution (captured $\mathrm{CO}_{2}$ ) reached a concentration of $2.7 \mathrm{M}$. Several dilutions of the stock solutions in DI water were prepared, and ionic conductivities were measured as shown in Figure 2 . As the cathode electrode is separated from the CEM, ionic conductivity becomes a significant parameter in controlling electrode polarization and reaction efficiencies. With the aim to have the highest concentration of $\mathrm{CO}_{2}$ stoichiometrically proportional to $\mathrm{CHP}$ ), with the highest ionic conductivity, $1.25 \mathrm{M}$ $\mathrm{CHP}-\mathrm{H}_{2} \mathrm{CO}_{3}\left(20 \mathrm{mS} \mathrm{cm}{ }^{-1}\right)$ was used from this point forward to perform the electrochemical reduction experiments.

Proof of concept experiments were performed at constant current density of $100 \mathrm{~mA} \mathrm{~cm}^{-2}$ during $30 \mathrm{~min}$ at 0 psig and 20 psig cathode side back pressure (self pressurized). Analysis of the produced gases demonstrated the presence of $\mathrm{CO}$ and an $\mathrm{H}_{2}$ as products of the $\mathrm{CHP}-\mathrm{H}_{2} \mathrm{CO}_{3}$ electrolysis as well as $\mathrm{CO}_{2}$ released from the $\mathrm{CHP}-\mathrm{H}_{2} \mathrm{CO}_{3}$ solution. Other experiments, not reported here, were performed at lower current densities where $\mathrm{CO}$ was not observed in the gas product. A summary of the produced gas concentrations and volumes for all the experiments reported in this paper is shown in Table S1 ESI. In the liquid stream, two phases were observed, being the top phase released CHP, and the bottom phase the aqueous solution with unreacted $\mathrm{CHP}-\mathrm{H}_{2} \mathrm{CO}_{3}$. Hydrogen was the main product in the gas stream and low CO FE of $1.1 \%$ and $2.9 \%$ were observed at 0 psig and 20 psig, respectively. On the other hand, higher amounts of $\mathrm{CO}_{2}$ were released when no back pressure was applied.

These results suggest a beneficial effect on the back pressure possibly re-dissolving unreacted $\mathrm{CO}_{2}$, hence increasing the efficiency for $\mathrm{CO}$ production. During the operation the cell potential varied from ca $5.5 \mathrm{~V}$ to $4.5 \mathrm{~V}$. High electrode polarization induced by the low ionic conductivity was then attributed to be one of the main causes for high voltage.

Addition of a supporting electrolyte was investigated to increase the ionic conductivity of the $\mathrm{CHP}-\mathrm{H}_{2} \mathrm{CO}_{3}$ solution. $\mathrm{KHCO}_{3}$ was tested as the first option. However, upon the addition of $\mathrm{KHCO}_{3}$ some phase separation in the liquid phase was observed, which was associated with the release of some of $\mathrm{CO}_{2}$ from the $\mathrm{CHP}-\mathrm{H}_{2} \mathrm{CO}_{3}$ solution. $\mathrm{K}_{2} \mathrm{SO}_{4}$ was tested as supporting electrolyte as it has been previously proved to be a suitable electrolyte for $\mathrm{CO}_{2}$ reduction. ${ }^{17,}{ }^{32}$ Diluted $\mathrm{CHP}-\mathrm{H}_{2} \mathrm{CO}_{3}$ solutions with $0.2 \mathrm{M} \mathrm{K}_{2} \mathrm{SO}_{4}$ were prepared from the stock $\mathrm{CHP}-\mathrm{H}_{2} \mathrm{CO}_{3}$. Hence the ionic conductivity was measured as shown in Figure 2. A $47 \%$ increase in conductivity was observed for the $1.25 \mathrm{M} \mathrm{CHP}-\mathrm{H}_{2} \mathrm{CO}_{3}$ solution with $0.2 \mathrm{M} \mathrm{K}_{2} \mathrm{SO}_{4}$. Nevertheless, close to a 10 fold increase in the $\mathrm{CO}$ production and FE were obtained during the electrochemical reduction experiments.

Figure 3 shows the composition of gases produced during the electrochemical synthesis of syngas from captured $\mathrm{CO}_{2}$ at $25{ }^{\circ} \mathrm{C}, 20$ psig back pressure and current densities from 26 to $104 \mathrm{~mA} \mathrm{~cm}^{-2}$. Using similar charge, experiments at various current densities were performed with electrolysis time varied accordingly. The highest $\mathrm{CO}$ concentration was obtained at $78 \mathrm{~mA} \mathrm{~cm}^{-2}$, which corresponded to a $\mathrm{H}_{2}: \mathrm{CO}$ ratio of 2.6 (Figure 3). It is worth noting that the amount of $\mathrm{CO}_{2}$ released from the $\mathrm{CHP}-\mathrm{H}_{2} \mathrm{CO}_{3}$ solution 
increased as the current increased (Figure $\mathrm{S} 1$ ). $\mathrm{CO}_{2}$ release is expected to be driven by proton transfer from the anode as well as coulombic heating near the cathode surface which decomposes the CHP$\mathrm{H}_{2} \mathrm{CO}_{3}$ acid base pair. Slow release of $\mathrm{CO}_{2}$ at low current densities may affect the $\mathrm{CO}_{2}$ availability for reaction and, therefore, the reaction yields at low current densities. At $104 \mathrm{~mA} \mathrm{~cm}^{-2}$, higher electrode polarization, which favor hydrogen evolution over $\mathrm{CO}_{2}$ reduction, may be one of the main causes for the decrease in the $\mathrm{CO}$ yield. However, a higher $\mathrm{CO}_{2}$ release rate may have also affected the residence time of $\mathrm{CO}_{2}$ within the electrochemical reactor causing lower $\mathrm{CO}_{2}$ conversion. The syngas concentration profile on Figure 3 also shows that, except for the process at $26 \mathrm{~mA} \mathrm{~cm}^{-2}$, the $\mathrm{CO}_{2}$ concentration in the produced gas is lower than the amount of $\mathrm{CO}$ produced. For the first time it was demonstrated that syngas can be directly produced from captured $\mathrm{CO}_{2}$ eliminating the requirement of downstream separations. As it is shown in Figure 3 this process produced syngas with commercial characteristics, 2 to $4 \mathrm{H}_{2}$ :CO ratios, and at current densities as high as $104 \mathrm{~mA} \mathrm{~cm} 2$.

Based on the proof of concept results, and published data at high pressure $\mathrm{CO}_{2}$ reduction, ${ }^{17,33}$ it is clear that high pressures enhanced the $\mathrm{CO}_{2}$ reduction efficiency. A simple parametric analysis was performed to evaluate the effect of the back pressure at a current density of $104 \mathrm{~mA} \mathrm{~cm}{ }^{-2}$. The results, which are shown in Figure 4, include the FE profiles for the experiments performed at $20 \mathrm{psig}$, and one test performed at $78 \mathrm{~mA} \mathrm{~cm}^{-2}$ and $40 \mathrm{psig}$. The results show that at $104 \mathrm{~mA} \mathrm{~cm}^{-2}$ the CO FE increased over $20 \%$ with an increase in the back pressure from 20 to 40 psig. Over $100 \%$ increase can be observed when the FE of $\mathrm{CO}$ at 0 and 40 psig are compared. An $8.5 \%$ increase in the FE was also observed for the $75 \mathrm{~mA} \mathrm{~cm}^{-2}$ when the back pressure was increased from 20 to 40 psig. These results clearly show the beneficial effect of the back pressure in the efficiency of the electrochemical reduction of $\mathrm{CO}_{2}$. Enhancing the contact of the released $\mathrm{CO}_{2}$ and the electro-catalyst $\left(\mathrm{CO}_{2}\right.$ residence time) significantly favors the $\mathrm{CO}_{2}$ reduction. Higher pressures were not tested due to design restrictions on the materials used for the electrochemical set up. However, pressure differentials as high as 87 psig have been reported for Nafion membranes. ${ }^{34}$

It is also observed on Figure 4 that the sum of $\mathrm{CO}$ and $\mathrm{H}_{2} \mathrm{FEs}$ are close to $100 \%$ for all the experimental conditions. Hence no significant quantities of other $\mathrm{CO}_{2}$ reduction products, such as formate, are expected. GC analysis of the reacted catholyte solutions (Figure S2) confirm the absence of formate, the other product most likely produced from $\mathrm{CO}_{2}$ reduction, in detectable quantities. Moreover, the chromatograms on Figure S2 confirm no appreciable degradation of the SPS. Hence, it is rasonable to

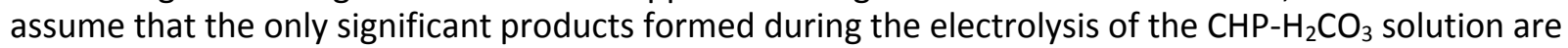
$\mathrm{CO}$ and $\mathrm{H}_{2} \cdot \mathrm{CO}_{2}$ conversions can be calculated based on the amount of $\mathrm{CO}_{2}$ released from the $\mathrm{CHP}-\mathrm{H}_{2} \mathrm{CO}_{3}$ solution during the test (unreacted $\mathrm{CO}_{2}+\mathrm{CO}_{2}$ converted to $\mathrm{CO}$ ). The results, which are shown on Figure 5 show that $\mathrm{CO}_{2}$ conversions and yields were as high as $71.7 \%$ during the electrochemical production of syngas from $\mathrm{CO}_{2}$ captured in SPS at $104 \mathrm{~mA} \mathrm{~cm}^{-2}, 40 \mathrm{psig}$, and $25{ }^{\circ} \mathrm{C}$. For these conditions the measured $\mathrm{H}_{2}$ : $\mathrm{CO}$ ratio was 2.4. It can also be conclude from Figures 3 and 4 that operation parameters, such as current density and cathode back-pressure, can be controlled to tailor the produced syngas $\mathrm{H}_{2}: \mathrm{CO}_{\text {ratio }}$ in a range from 2 to 7 as an advantage for downstream conversion. ${ }^{13}$

A transient analysis was performed to evaluate the characteristics of the syngas product and system performance during an extended period of time (105 $\mathrm{min})$. For this purpose, the system was operated at the best obtained conditions $\left(100 \mathrm{~mA} \mathrm{~cm}^{-2}, 40 \mathrm{psig}\right.$, and $\left.25{ }^{\circ} \mathrm{C}\right)$, collecting samples every 15 minutes for $\mathrm{GC}$ analysis. The $\mathrm{CHP}-\mathrm{H}_{2} \mathrm{CO}_{3}$ solution was kept on recirculation and without external additions of fresh solution. The results in Figure 6, show that at the beginning, while the process has not yet reached the desired operating pressure and builds an adequate concentration of free $\mathrm{CO}_{2}$, the efficiencies for $\mathrm{CO}$ production are low. Close to $13 \%$ of the volume of gas collected during the first sample corresponded to air displaced from the system as electrochemically generated gas started evolving. The highest $\mathrm{CO}_{2}$ reduction efficiency was measured for the second gas sample after stabilization of the pressure in the system. Then the relative $\mathrm{CO}$ yield starts decreasing, $\mathrm{H}_{2}$ increases, possibly by the depletion of $\mathrm{CO}_{2}$ available derived from the decrease of the $\mathrm{CHP}-\mathrm{H}_{2} \mathrm{CO}_{3}$ concentration in the recirculated solution (Figure S3). Decrease of the $\mathrm{CHP}-\mathrm{H}_{2} \mathrm{CO}_{3}$ concentration is enhanced by the water transferred from the anode due to electro-osmotic drag. Nevertheless, during the transient performance analysis it is also observed that 
the $\mathrm{CO}_{2}$ conversion remains considerably stable, with a slight $4.3 \%$ decrease over a 90 min period (points two and four in Figure $6 \mathrm{~b}$ ). The fact that the $\mathrm{CO}_{2}$ conversion remains stable during the operation supports the conclusion that decrease in $\mathrm{CO}$ yield during time is mainly caused by the depletion of captured $\mathrm{CO}_{2}$ rather than catalyst deactivation. A continuous process feeding fresh solution and removing spent solution and the product gases may allow the continue production of syngas with stable compositions.

For this last experiment lower $\mathrm{CO}$ concentrations and a higher $\mathrm{H}_{2}: \mathrm{CO}$ ratios were obtained in comparison with the results at the same conditions reported in Figures 5 and 6 . Electrode aging could be one of the reasons for performance decrease. However a more detailed study of changes in the electrode surface post-reaction will be necessary to identify the real cause of activity decrease, which falls out of the scope of this paper.

\section{Conclusions}

SPS were used as capture-electrolyte media for the electrochemical production of syngas. For the first time captured $\mathrm{CO}_{2}$ was electrochemically reduced to $\mathrm{CO}$ without the need to feed additional $\mathrm{CO}_{2}$ gas to the electrochemical cell. The system greatly simplifies the electrolysis cell by eliminating the need to introduce gas efficiently to the cathode such as required with a gas diffusion electrode. The developed process allows the release and reduction of captured $\mathrm{CO}_{2}$ in a single electrochemical cell, while the capture media can be recovered to continue the CCU cycle. A non diluted syngas stream was obtained at $104 \mathrm{~mA} \mathrm{~cm}{ }^{-2}$ with $\mathrm{H}_{2}: \mathrm{CO}$ ratios as low as 2.4 and with $\mathrm{CO}_{2}$ conversions up to $71.7 \%$.

\section{Experimental}

Electrochemical reduction of captured $\mathrm{CO}_{2}$ was performed in a $10 \mathrm{~cm}^{2}$ (Fuel Cell technology, Inc.) cell test station customized with titanium plate current collectors (end plates) and connected to a BK Precision 1739 DC power supply (Figure 1). On the anode side Pt plated sintered titanium (Ginner, inc.), attached to a proton exchange membrane (PEM) 117 Nafion was used as electro-catalyst for water oxidation. A Master Flex C/L peristaltic pump was used to recirculate the anolyte in the anode chamber through a serpentine flow pattern engraved in the Ti current collector. In the cathode chamber, the cathode current collector was modified by removing the flow channels and replacing them with a hollow compartment that can fit a porous electrode with $10 \mathrm{~cm}^{2}$ projected geometric area and $1.5 \mathrm{~mm}$ thickness. The electrode and the PEM were separated by an ultra-thin polyester fabric $(178 \mu \mathrm{m}) .15 \mathrm{~mL}$ of the catholyte solution with the captured $\mathrm{CO}_{2}$ were recirculated to flood the cathode chamber, and into a recirculation reservoir that served as phases separator, using a bench-top Cole Parmer gear pump system. Aqueous phase was recirculated from the bottom of the phase separator while the organic phase remained at the top of the contained liquid (Figure 1 a). All the $\mathrm{CO}_{2}$ added to the electroyzer came from the captured form and no additional $\mathrm{CO}_{2}$ gas was added directly to the electrolyzer and/or to the capture media during operation. Once the desired current was applied the cathode side was allowed to self-pressurize by the gases produced at the cathode chamber. The pressure on the cathode side was manually controlled using a needle valve and the gases were collected in a Restek Multilayer bag, for gas chromatography (GC) analysis. Electrochemical reduction experiments were performed at different current densities from 25 to $100 \mathrm{~mA} \mathrm{~cm}^{-2}$, back pressures of 0,20 , and $40 \mathrm{psig}$, and constant temperature of $25{ }^{\circ} \mathrm{C}$. Temperature controller and heating units built in the cell test were used to keep the temperature constant during operation.

\section{Electrode preparation}

The cathode electrode was prepared by spraying a silver catalyst ink on a reticulated vitreous carbon (RVC) foam 80 nominal number of pores per inch of foam and $1.5 \mathrm{~mm}$ thick. Ag powder (1-3 $\mu \mathrm{m}$, Alfa 
Aesar) was used as the catalyst. To prepare the catalyst ink Ag powder was mixed in a solution prepared with 2-propanol (Fluka analyitical), Nafion perfluorinated resin solution (5\%, Aldrich), and

polytetrafluorethylene (PTFE) preparation (60\%, Aldrich), to reach a final catalyst composition of 80 wt\% $\mathrm{Ag}, 10 \mathrm{wt} \%$ Nafion, and $10 \mathrm{wt} \%$ PTFE. The actual catalyst loading was determined by weighing the RVC before and after painting. Several electrodes were prepared following the same procedure, which were used to perform preliminary and proof of concept experiments. However, all the results reported in this paper, after the addition of a supporting electrolyte, were obtained with the same cathode electrode, which reached an $\mathrm{Ag}$ loading of $25 \mathrm{mg} \mathrm{cm}^{-2}$.

\section{$\mathrm{CO}_{2}$ capture}

Deionized water and 1-Cyclohexylpiperidine (CHP), obtained from Alfa Aesar, were used for the capture of $\mathrm{CO}_{2}$ in a modular gas contactor that allows continuous production of $\mathrm{CHP}-\mathrm{H}_{2} \mathrm{CO}_{3}$ solutions. ${ }^{28}$ In brief, The $\mathrm{CO}_{2}$ gas and the liquid streams (water and CHP) were put in contact in a gas diffusion membrane unit with gas and liquids fed in opposite sides of the membrane. The membrane provides an enhanced mass transfer area that allows the diffusion of the $\mathrm{CO}_{2}$ gas through the membrane and into the water$\mathrm{CHP}$ mixture at efficient and controllable rates. A scheme of the apparatus used for $\mathrm{CO}_{2}$ captured is shown in Figure $\mathrm{S} 4, \mathrm{ESI}$. The $\mathrm{CHP}-\mathrm{H}_{2} \mathrm{CO}_{3}$ solution was recirculated in the $\mathrm{CO}_{2}$ capture system until a homogenous stock solution with a target concentration of $3 \mathrm{M}$ was achieved. $\mathrm{CO}_{2}$ capture was performed at room temperature.

\section{Analysis}

Concentration of the $\mathrm{CHP}-\mathrm{H}_{2} \mathrm{CO}_{3}$ stock solution and catholyte were measured using an Agilent $7890 \mathrm{GC}$ equipped with a 7693 auto-sampler and a flame ionization detector (FID). The gases produced during the electrochemical reduction of $\mathrm{CO}_{2}$ were analysed in a Hewlett Packard $5890 \mathrm{GC}$ equipped with two TCD detectors and two columns. A molecular sieve $5 \mathrm{~A}$ and argon as gas carrier were used for the detection and quantification of CO, while a capillary column 2C D-poraPLOTU and helium gas carrier were used for the detection and quantification of $\mathrm{CO}_{2}$. Finally, the volume of collected gas was measured using a Hamilton, Co. model s-1000 syringe. From the product analysis, syngas compositions, faradaic efficiencies (FE), and $\mathrm{CO}_{2}$ conversions were determined.

\section{Conflicts of interest}

There are no conflicts to declare.

\section{Acknowledgements}

This work was supported through the INL Laboratory Directed Research\& Development (LDRD) Program under DOE Idaho Operations Office Contract DE-AC07- 05ID14517.

This manuscript has been authored by Battelle Energy Alliance, LLC under Contract No. DE-AC0705ID14517 with the U.S. Department of Energy. The United States Government retains and the publisher, by accepting the article for publication, acknowledges that the United States Government retains a nonexclusive, paid-up, irrevocable, world-wide license to publish or reproduce the published form of this manuscript, or allow others to do so, for United States Government purposes.

\section{Notes and references}

1. G. Centi and S. Perathoner, Catalysis Today, 2009, 148, 191-205.

2. N. Mac Dowell, P. S. Fennell, N. Shah and G. C. Maitland, Nature Climate Change, 2017, 7, 243249. 
3. F. A. Rahman, M. M. A. Aziz, R. Saidur, W. A. W. A. Bakar, M. R. Hainin, R. Putrajaya and N. A. Hassan, Renewable and Sustainable Energy Reviews, 2017, 71, 112-126.

4. B. Lv, B. Guo, Z. Zhou and G. Jing, Environ. Sci. Technol., 2015, 49, 10728-10735.

5. B. Dutcher, M. Fan and A. G. Russell, ACS Applied Materials \& Interfaces, 2015, 7, 2137-2148.

6. F. A. Chowdhury, H. Yamada, T. Higashii, K. Goto and M. Onoda, Industrial \& Engineering Chemistry Research, 2013, 52, 8323-8331.

7. D. B. Lao, B. R. Galan, J. C. Linehan and D. J. Heldebrant, Green Chemistry, 2016, 18, 4871-4874.

8. J. Kothandaraman, A. Goeppert, M. Czaun, G. A. Olah and G. K. Surya Prakash, Green Chemistry, 2016, 18, 5831-5838.

9. M. Gattrell, N. Gupta and A. Co, Journal of Electroanalytical Chemistry, 2006, 594, 1-19.

10. R. J. Lim, M. Xie, M. A. Sk, J.-M. Lee, A. Fisher, X. Wang and K. H. Lim, Catalysis Today, 2014, 233, 169-180.

11. J. Durst, A. Rudnev, A. Dutta, Y. Fu, J. Herranz, V. Kaliginedi, A. Kuzume, A. A. Permyakova, Y. Paratcha, P. Broekmann and T. J. Schmidt, CHIMIA International Journal for Chemistry, 2015, 69, 769-776.

12. S. Hernandez, M. Amin Farkhondehfal, F. Sastre, M. Makkee, G. Saracco and N. Russo, Green Chemistry, 2017, 19, 2326-2346.

13. K.-H. Liu, H.-X. Zhong, X.-Y. Yang, D. Bao, F.-L. Meng, J.-M. Yan and X.-B. Zhang, Green Chemistry, 2017, 19, 4284-4288.

14. M. B. Ross, C. T. Dinh, Y. Li, D. Kim, P. De Luna, E. H. Sargent and P. Yang, Journal of the American Chemical Society, 2017, 139, 9359-9363.

15. A. Sternberg, C. M. Jens and A. Bardow, Green Chemistry, 2017, 19, 2244-2259.

16. S. Ma and P. J. Kenis, Current Opinion in Chemical Engineering, 2013, 2, 191-199.

17. E. J. Dufek, T. E. Lister, S. G. Stone and M. E. Mcllwain, Journal of The Electrochemical Society, 2012, 159, F514-F517.

18. A. J. Martin, G. O. Larrazabal and J. Perez-Ramirez, Green Chemistry, 2015, 17, 5114-5130.

19. B. Kumar, J. P. Brian, V. Atla, S. Kumari, K. A. Bertram, R. T. White and J. M. Spurgeon, Catalysis Today, 2016, 270, 19-30.

20. S. Verma, X. Lu, S. Ma, R. I. Masel and P. J. A. Kenis, Physical Chemistry Chemical Physics, 2016, 18, 7075-7084.

21. J. Zhang, L. Chen, F. Li, Y. Zhang, C. Bentley, M. Horne and A. Bond, ChemSusChem, DOI: 10.1002/cssc.201701075, n/a-n/a.

22. R. Kortlever, K. H. Tan, Y. Kwon and M. T. M. Koper, Journal of Solid State Electrochemistry, 2013, 17, 1843-1849.

23. C. Delacourt, P. L. Ridgway, J. B. Kerr and J. Newman, Journal of The Electrochemical Society, 2008, 155, B42-B49.

24. P. G. Jessop, S. M. Mercer and D. J. Heldebrant, Energy \& Environmental Science, 2012, 5, 72407253.

25. P. G. Jessop, L. Phan, A. Carrier, S. Robinson, C. J. Durr and J. R. Harjani, Green Chemistry, 2010, 12, 809-814.

26. P. G. Jessop, Aldrichimica Acta, 2015, 48, 18-21.

27. C. J. Orme and A. D. Wilson, Desalination, 2015, 371, 126-133.

28. D. Wendt, B. Adhikari, C. Orme and A. Wilson, Davis, California, 2016.

29. J. S. McNally, B. Noll, C. J. Orme and A. D. Wilson, The Journal of Physical Chemistry B, 2015, 119, 6766-6775.

30. A. D. Wilson and C. J. Orme, RSC Advances, 2015, 5, 7740-7751.

31. A. D. Wilson and F. F. Stewart, RSC Advances, 2014, 4, 11039-11049. 
32. E. J. Dufek, T. E. Lister and M. E. Mcllwain, Electrochemical and Solid-State Letters, 2012, 15, B48-B50.

33. H. Kohjiro and S. Tadayoshi, Bulletin of the Chemical Society of Japan, 1997, 70, 571-576.

34. J. A. Staser and J. W. Weidner, Journal of The Electrochemical Society, 2009, 156, B16-B21. 

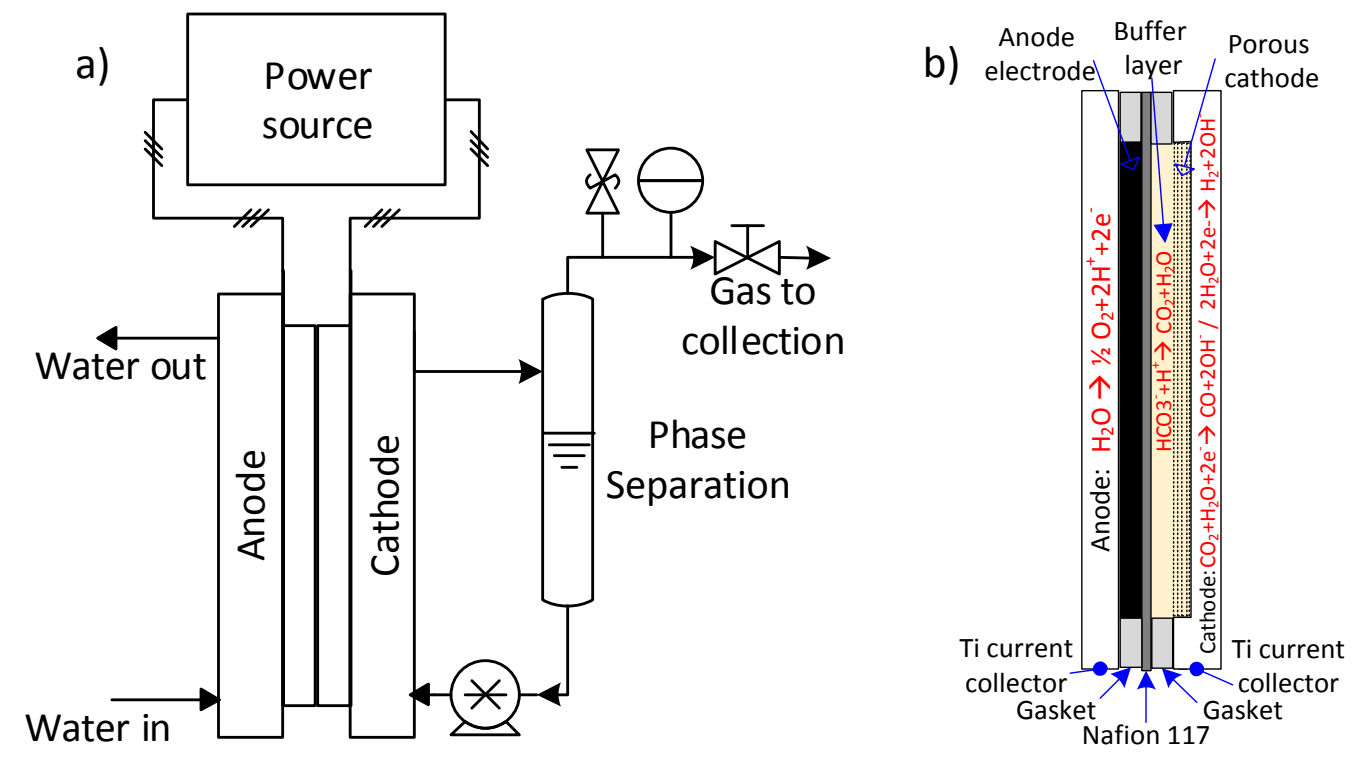

Figure 1. a) scheme of the electrolysis system for the reduction of captured $\mathrm{CO}_{2}$, b) description of the MEA. 


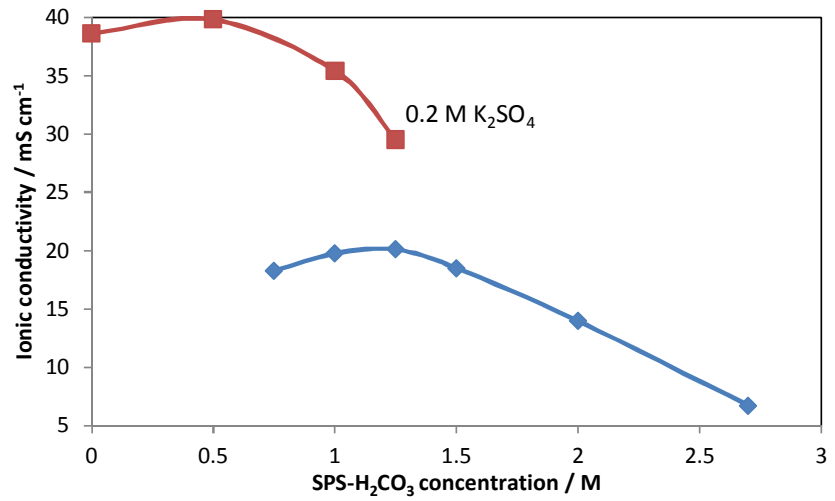

Figure 2. Ionic conductivity of $\mathrm{CHP}-\mathrm{H}_{2} \mathrm{CO}_{3}$ solutions in the presence and absence of $0.2 \mathrm{M} \mathrm{K}_{2} \mathrm{SO}_{4}$. 


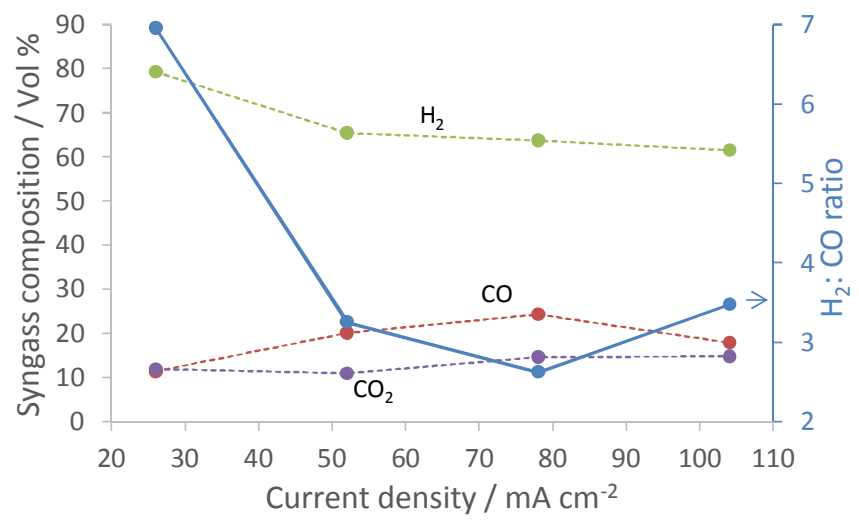

Figure 3. Composition profile and $\mathrm{H}_{2}: \mathrm{CO}$ ratio for the syngas obtained at different current densities and at 20 psig back pressure in the cathode side. 


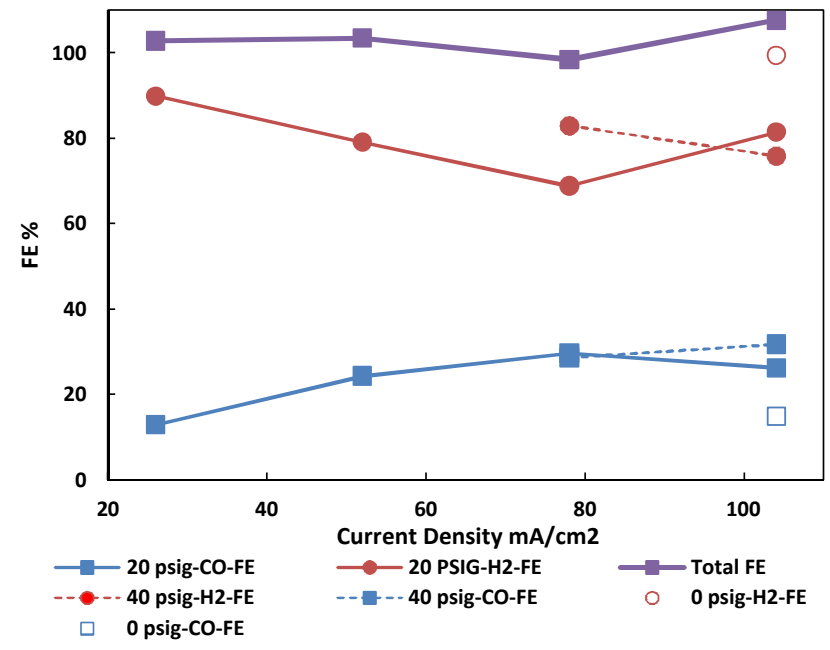

Figure 4. Faradic efficiencies of syngas produced from captured $\mathrm{CO}_{2}$ at different current and pressures. 


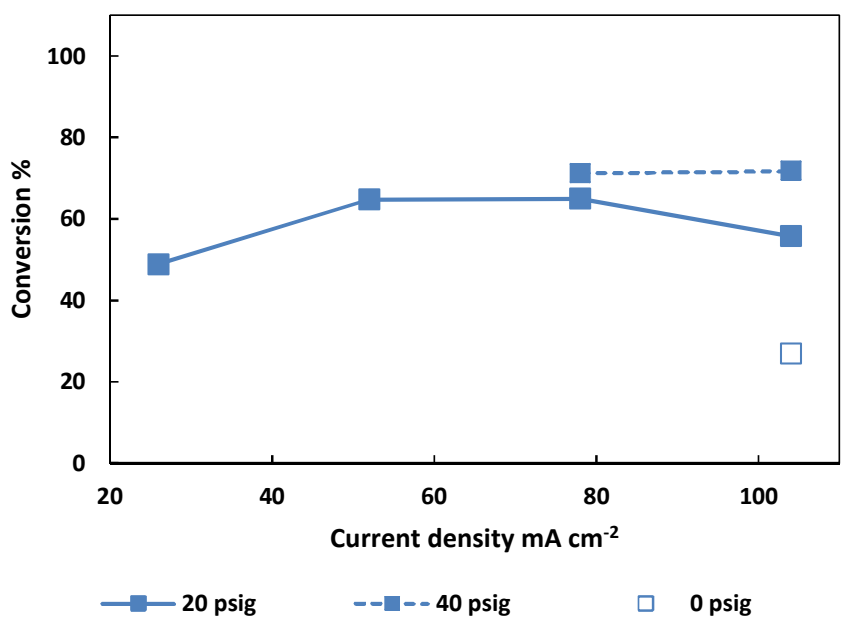

Figure 5. Conversion profiles for $\mathrm{CO}_{2}$ released from the $\mathrm{CHP}-\mathrm{H}_{2} \mathrm{CO}_{3}$ solution. 

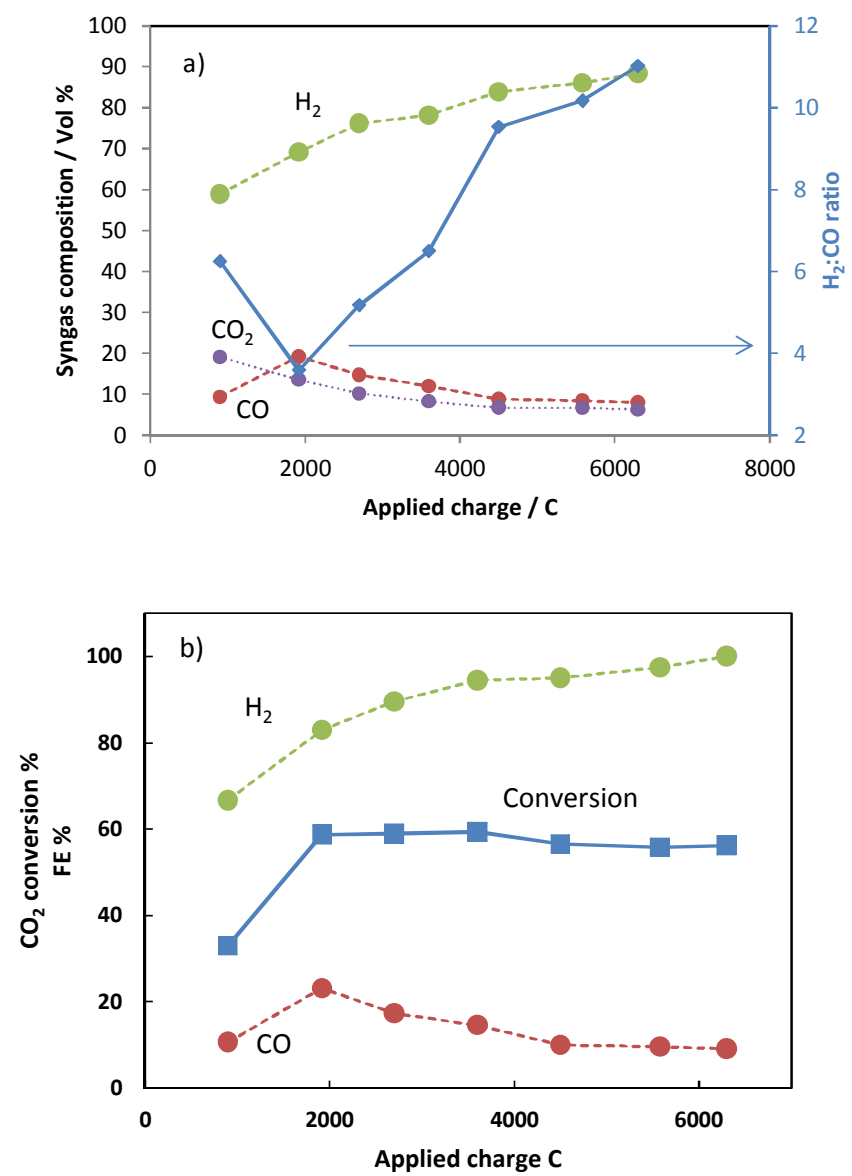

Figure 6. a) Concentration profiles of the syngas stream b) $\mathrm{FE}$ and $\mathrm{CO}_{2}$ conversion. 